\title{
Peran Delta Neutrophil Index sebagai Prediktor Sepsis pada Anak
}

Lucky Yogasatria Natasukma, Pudjiastuti, Sri Martuti

Bagian Ilmu Kesehatan Anak Fakultas Kedokteran Universitas Sebelas Maret, Surakarta

Latar belakang. Sepsis adalah disfungsi organ yang mengancam kehidupan yang disebabkan oleh disregulasi imun terhadap infeksi. Dalam keadaan stres atau infeksi, neutrofil imatur dilepas ke sirkulasi. Delta Neutrophil Index (DNI) dapat mencerminkan jumlah granulosit imatur di sirkulasi. Di Indonesia, belum ada penelitian manfaat DNI pada populasi anak.

Tujuan. Untuk mengetahui peran DNI sebagai prediktor sepsis pada anak.

Metode. Penelitian observasional analitik dengan menggunakan studi potong lintang. Subjek penelitian adalah anak usia 1 bulan-18 tahun yang dirawat di PICU dan HCU anak, RSUD Dr. Moewardi, Surakarta, dengan kecurigaan infeksi antara bulan Januari sampai November 2018. Setiap subjek diukur kadar DNI dan dikategorikan sepsis atau tidak sepsis. Kemampuan diagnosis DNI dinyatakan sebagai sensitivitas, spesifisitas, nilai duga positif, nilai duga negatif, rasio kemungkinan positif, rasio kemungkinan negatif, akurasi dan post-test probability.

Hasil. Cut-off DNI $\geq 2,7 \%$ didapatkan peningkatan risiko 33 kali untuk seseorang terkena sepsis, dengan sensitivitas $84,6 \%$, spesifitas $85,7 \%$, nilai duga positif positif $78,6 \%$, nilai duga negatif sebesar $90 \%$, rasio kemungkinan positif 5,9 , sedangkan rasio kemungkinan negatif 0,2 serta akurasi $82,3 \%$, dengan post test probability meningkat $26,8 \%$.

Kesimpulan. Delta neutrofil indeks dapat digunakan sebagai prediktor sepsis pada anak. Sari Pediatri 2019;21(2):115-20

Kata kunci: sepsis, neutrofil, DNI, anak

\section{Delta Neutrophils Index as a Sepsis Predictor in Children}

Lucky Yogasatria Natasukma, Pudjiastuti, Sri Martuti

Background. Sepsis is a life threatening multiple organ dysfunction due to immune system dysregulation caused by infection. Under stress or infection, immature neutrophils will be released to blood circulation. Delta Neutrophils Index (DNI) could determine the presence of immature granulocytes in circulation. In Indonesia, research pertaining DNI role as sepsis predictor in children has not been done.

Objective. To find out the role of DNI as a predictor of sepsis in children.

Methods. observational analytic research using cross sectional model. The research subjects are from age 1 month to 18 years old who received treatment at PICU and HCU at Dr. Moewardi Regional State Hospital Surakarta suspected having infection, between Januari November 2018. DNI rate of every subject were measeured and categorized whether it is sepsis or not. DNI diagnostic significance as sepsis predictor are stated as sensitivity, specificity, positive predictive value, negative predictive value, positive probability ratio, negative probability ratio, accuracy, and post test probability.

Result. With DNI cut-off rate of $\geq 2.7 \%$, there were 33 times increased chance for patient getting sepsis with sensitivity of $84,6 \%$, spesificity $85,7 \%$, positive predictive value $78,6 \%$, negative predictive value $90 \%$, positive probability ratio 5,9 negative probability ratio0,17 accuracy of $82,3 \%$, with post test probability increasing $26,8 \%$.

Conclusion. Delta neutrophils index can be used as sepsis predictor in children. Sari Pediatri 2019;21(2):115-20

Keywords: sepsis, neutrophyle, DNI, children

Alamat korespondensi: Lucky Yogasatria Natasukma. Departemen Ilmu Kesehatan Anak Fakultas Kedokteran UNS. Email: dr.luckyyoga@gmail.com 
S epsis adalah disfungsi organ yang mengancam kehidupan (life-threatening organ dysfunction) yang disebabkan oleh disregulasi imun terhadap infeksi. ${ }^{1}$ Pada unit perawatan intensif anak di seluruh dunia, prevalensi sepsis $8,2 \% .{ }^{2} \mathrm{Di}$ unit perawatan intensif anak Rumah Sakit Cipto Mangunkusumo (RSCM), sejumlah 19,3\% dari 502 pasien anak yang dirawat mengalami sepsis dengan angka mortalitas 54\%. Respon imun terhadap bakteri dapat menyebabkan disfungsi organ atau sepsis dan syok septik dengan angka mortalitas relatif tinggi. ${ }^{3}$

Langkah pertama untuk penegakan diagnosis sepsis adalah identifikasi faktor predisposisi infeksi, yaitu usia, status nutrisi, status imunisasi, keadaan komorbid (penyakit kronis, keganasan, kelainan bawaan, transplantasi) dan riwayat terapi (steroid, antibiotik, tindakan invasif). Kriteria diagnosis dari sepsis ditegakkan berdasarkan adanya (1) infeksi, meliputi (a) faktor predisposisi infeksi, (b) tanda atau bukti infeksi yang sedang berlangsung dan (2) tanda disfungsi atau gagal organ. Kecurigaan infeksi jika didapatkan dua atau lebih dari keadaan suhu lebih $>38^{\circ}$ atau $<36^{\circ} \mathrm{C}$ aksilar,

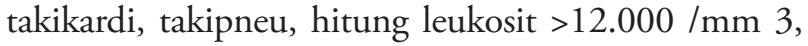
$<4.000 / \mathrm{mm} 3$ atau ditemukan $>10 \%$ sel darah putih. Sementara disfungsi organ ditegakkan berdasarkan skor PELOD-2. Diagnosis sepsis ditegakkan bila skor $\geq 11$ (atau $\geq 7$ pada RS tipe B-C).

Normalnya, hampir semua neutrofil yang dilepas ke sirkulasi dari sumsum tulang dalam bentuk neutrofil segmen. Namun, dalam stres atau infeksi, neutrofil yang kurang matang dilepas ke sirkulasi, termasuk neutrofil batang. Keadaan ini meningkatkan neutrofil kurang matang (immature) yang disebut pergeseran ke kiri atau left-shift, yang didefinisikan sebagai peningkatan rasio immature granulocytes/ total granulosit. Pergeseran kiri yang lebih besar mengindikasikan konsumsi neutrofil yang lebih besar pada lokasi yang terinfeksi dan produksi neutrofil yang lebih besar di sumsum tulang. Parameter DNI diukur dengan alat hematologi otomatis yang mencerminkan jumlah granulosit imatur di sirkulasi. ${ }^{4}$ Beberapa penelitian di Indonesia mengenai manfaat DNI masih sangat terbatas. Penelitian manfaat DNI pada populasi anak masih belum ada sehingga mendorong penulis peneliti untuk meneliti hal tersebut,

\section{Metode}

Penelitian ini adalah penelitian observasional analitik dengan studi potong lintang yang dilakukan di RS Dr. Moewardi Surakarta dari bulan Januari sampai dengan November 2018. Sampel penelitian adalah pasien yang dirawat di Ruang PICU dan HCU anak Rumah Sakit Dr. Moewardi yang memenuhi kriteria inklusi serta tidak memenuhi kriteria eksklusi sampai besar sampel minimal terpenuhi. Sebelumnya, orangtua/ wali menandatangani lembar persetujuan mengikuti penelitian. Kriteria inklusi, antara lain, anak yang berusia 1 bulan-18 tahun yang dirawat di PICU dan HCU anak, RSUD Dr. Moewardi, Surakarta dengan kecurigaan infeksi. Kriteria eksklusi, antara lain, pasien penderita keganasan hematologi, seperti leukemia, pasien yang mendapatkan terapi granulocyte colony stimulating factors, pasien pasien defisiensi imunitas baik oleh infeksi Human immunodeficiency virus (HIV) atau pasien yang mendapatkan terapi prednisolone dengan dosis $2 \mathrm{mg} / \mathrm{kg} /$ hari selama paling sedikit 1 minggu, atau dengan dosis $1 \mathrm{mg} / \mathrm{kgbb} /$ hari selama 1 bulan atau terapi immunosupresan lain maksimal 3 bulan sebelum penelitian dimulai dan pasien atau orang tua menolak ikut penelitian.

Karakteristik dasar subyek penelitian (usia, jenis kelamin, penyakit dasar, tanda vital, GCS, refleks pupil, nilai DNI, nilai laktat, kreatinin, $\mathrm{PaO}_{2}, \mathrm{PaCO}_{2}$ ) menggunakan data rerata. Akurasi DNI dengan titik potong dianalisis dengan menggunakan uji diagnostik. Baku emas diagnosis sepsis digunakan kriteria sepsis. Penentuan titik potong DNI digunakan hasil penelitian sebelumnya oleh Seok dkk, ${ }^{5}$ yaitu 2,7\%. Analisis data digunakan program SPSS 20.0. Uji hipotesis digunakan uji koperatif kategorik tidak berasangan berupa chisquare, dengan uji alternated dengan Fischer exact test bila syarat chi-square tidak terpenuhi. Hasil disebut bermakna jika $\mathrm{p} \leq 0,05$. Kemampuan diagnosis DNI akurasi dinyatakan sebagai sensitivitas, spesifisitas, nilai duga positif, nilai duga negatif, rasio kemungkinan positif, rasio kemungkinan negatif, akurasi dan posttest probability. Penelitian ini sudah memperoleh kelaikan etik dan dinyatakan layak etik oleh Komisi Etik Penelitian Kesehatan RS Dr. Moewardi/Fakultas Kedokteran Universitas Sebelas Maret.

\section{Hasil}

Penelitian ini menggunakan data dari 34 sampel yang masuk dalam kriteria inklusi maupun eksklusi. Karakteristik dan demografi penelitian tertera pada 
Tabel 1. Karakteristik demografi subjek penelitian

\begin{tabular}{lcccc}
\hline & $\mathrm{N}$ & $(\%)$ & Rerata & \pm SD \\
\hline Jenis kelamin & & & & \\
$\quad$ Laki-laki & 21 & $(61,8)$ & & \\
$\quad$ Perempuan & 13 & $(38,2)$ & & $\pm 9,94$ \\
Usia & & & 12,28 & $\pm 1,93$ \\
BB & & & 6,62 & $\pm 0,84$ \\
Skor PELOD & & & & \\
Sepsis & 13 & $(38,2)$ & & \\
$\quad$ Sepsis & 21 & $(61,8)$ & & \\
$\quad$ Tidak sepsis & & & & \\
Nilai DNI & 8,787 & & & \\
$\quad$ Tertinggi & 0,002 & & & \\
$\quad$ Terendah & 20 & $(58,8)$ & & \\
$\quad<2,7 \%$ & 14 & $(41,2)$ & & \\
$\quad$ L2,7\% & & & & \\
$\quad$ Hidup & 20 & $(58,8)$ & & \\
$\quad$ Meninggal & 14 & $(41,2)$ & & \\
& & & & \\
\hline
\end{tabular}

Tabel 2. Crosstable antara DNI dengan kejadian sepsis

\begin{tabular}{lccc}
\hline & Sepsis & Tidak sepsis & Total \\
\hline DNI tinggi $\geq 2,7 \%$ & $11(32,4)$ & $3(8,8)$ & $14(41,2)$ \\
DNI rendah $<2,7 \%$ & $2(5,9)$ & $18(52,9)$ & $20(58,8)$ \\
Total $(\%)$ & $13(38,2)$ & $21(61,8)$ & $34(100,0)$ \\
\hline
\end{tabular}

Tabel 1. Sampel penelitian ini mayoritas berkelamin pria $(61,8 \%)$. Rerata skor PELOD dari seluruh sampel tersebut sebesar 6,62. Mayoritas sampel (21) dinyatakan tidak sepsis. Nilai DNI 58\% dari semua sampel berada di bawah cut-off sepsis, dan angka mortalitas dari seluruh populasi $58,8 \%$.

Data DNI dan diagnosis sepsis yang sudah didapat dijabarkan melalui crossstable $2 \times 2$ untuk mempermudah interpretasi. Pada 13 orang subyek sepsis didapatkan, 11 di antaranya memiliki angka DNI $\geq 2,7 \%$ sesuai dengan kriteria cut-off DNI yang digunakan, sedangkan 2 subyek memiliki angka DNI rendah $<2,7 \%$. Pada 21 pasien yang didiagnosis tidak sepsis sesuai kriteria PELOD, 18 di antaranya memiliki angka DNI yang rendah $<2,7 \%$ dan 3 di antaranya memiliki nilai DNI yang tinggi $\geq 2,7 \%$. Crosstable penelitian tertera pada Tabel 2.

Berdasarkan hasil penghitungan chi-square menunjukkan $\mathrm{p}=0,001$ dengan interval kepercayaan 95\%. Hal tersebut berarti terdapat perbedaan signifikan pada variasi angka DNI antara kelompok subyek sepsis dan non sepsis. Analisis dilanjutkan dengan pengitungan odd rasio untuk melihat keterkaitan DNI dengan risiko kejadian sepsis. Hasil penghitungan menunjukkan data yang signifikan secara statisik. Peningkatan risiko 33 kali untuk seseorang terkena sepsis apabila angka $\mathrm{DNI} \geq 2,7 \%$ dengan $\mathrm{p}=0,001$ dan tingkat kepercayaan 95\% terletak antara 4,7-229,6, dengan sensitivitas $84,6 \%$, spesifitas $85,7 \%$, nilai duga positif positif $78,6 \%$, nilai duga negatif sebesar $90 \%$, rasio kemungkinan positif 5,9, sedangkan rasio kemungkinan negatif 0,2 serta akurasi $82,3 \%$ dengan post-test probability meningkat $26,8 \%$.

\section{Pembahasan}

Penelitian ini merupakan uji diagnostik untuk melihat nilai sensitivitas, spesifitas, nilai duga positif, nilai duga negatif, rasio kemunginan positif, rasio kemungkinan negatif serta akurasi DNI untuk menentukan diagnosis sepsis pada anak. 
Hasil penghitungan odd rasio menunjukkan kemungkinan terjadinya sepsis sebanyak 33 kali. Hal ini sesuai dengan penelitian sebelumnya yang melaporkan bahwa terdapat perbedaan yang bermakna antara nilai DNI pada kelompok subyek non sepsis dengan subyek sepsis. ${ }^{5}$

Pada uji diagnostik yang dilakukan pada DNI dalam memprediksi sepsis memiliki hasil yang baik, yaitu sensitivitas $84,6 \%$ dan spesifitas $85,7 \%$. Hasil sensitivitas dan spesitifitas DNI dalam memprediksi sepsis ini sejalan dengan hasil penelitian yang dilakukan Nahm dkk, ${ }^{6}$ yaitu dengan cut-off DNI 2,7\% memiliki sensitivitas $96,8 \%$ spesitifitas $93,5 \%$ serta akurasi $94 \%$. Sementara Seok dkk ${ }^{5}$ melaporkan sensitivitas $73,4 \%$ serta spesifisitas $97,9 \%$.

Nilai sensitivitas dan spesifisitas pada uji kali ini lebih rendah dibanding dengan uji pendahulu yang dilakukan oleh Nahm dkk ${ }^{6}$ dan Seok $\mathrm{dkk}^{5}$ diduga dipengaruhi oleh beberapa faktor. Faktor pertama yang mungkin menyebabkan perbedaan hasil sensitivitas adalah nilai cut-off diagnostik yang digunakan. Pada penelitian yang dilakukan oleh $\mathrm{Nahm} \mathrm{dkk},{ }^{6}$ digunakan nilai cut-off DNI yang bermakna berpengaruh terhadap kejadian sepsis pada 5\%. Nilai cut-off yang lebih tinggi ini akan memengaruhi jumlah subjek true positive karena jumlah false positive yang mungkin terdiagnosis sepsis menjadi terminimalisir. Namun, apabila nilai cut-offyang digunakan sebagai standar diagnostik sepsis ditingkatkan akan meningkatkan jumlah false negative yang mungkin menjadi tidak masuk dalam diagnosis sepsis. Sementara dalam perkembangan penyakitnya, keterlambatan dalam melakukan diagnosis awal dan pengobatan yang tepat untuk pasien sepsis dapat berakibat prognosis dan komplikasi yang lebih buruk. Dengan demikian, titik cut-off yang seimbang untuk mendapatkan nilai sensitivitas dan spesifisitas paling optimal perlu ditinjau kembali.

Faktor lain yang mungkin memengaruhi perbedaan hasil perhitungan sensitivitas dan spesifisitas DNI adalah usia dan respon inflamasi subjek. Pada penelitian pendahuluan yang dilakukan oleh Nahm dkk dan Seok dkk, subjek yang digunakan adalah subjek dewasa dengan rata-rata usia 59 dan 56 tahun, sedangkan pada studi ini berusia 1 bulan - 18 tahun dengan rata-rata usia subjek adalah 44 bulan. Usia subjek akan berpengaruh pada kematangan sistem imun tubuh dan respon imunitas terhadap inflamasi sistemik yang terjadi saat sepsis. Diduga, terjadi perbedaan indeks pergesaran granulosit meskipun penelitian yang ditujukan untuk membandingkan DNI pada kelompok usia bayi, anak, dan dewasa belum pernah dilakukan sebelumnya. ${ }^{7}$

Hasil dari nilai duga positif adalah 78,57\%, sedangkan nilai duga negatif sebesar 90\%. Nilai duga positif dan nilai duga negatif dipengaruhi oleh prevalensi penyakit. Oleh karena itu, kedua nilai ini akan berbeda jika dilakukan pada populasi dengan prevalensi penyakit yang berbeda. Penghitungan rasio kemungkinan adalah ukuran yang sangat berguna untuk menilai akurasi diagnostik. Rasio kemungkinan menyatakan bahwa besarnya kemungkinan subyek yang sakit akan mendapat suatu uji diagnostik tertentu dibagi kemungkinan subyek tidak sakit akan mendapat hasil uji yang sama. ${ }^{8}$ Rasio kemungkinan tergantung pada sensitivitas dan spesifitas. Namun begitu, rasio kemungkinan tidak dipengaruhi oleh prevalensi penyakit sehingga bermanfaat mengukur perubahan probabilitas penyakit dari hasil tes diagnostik negatif. Sementara rasio kemungkinan positif merupakan parameter yang tidak dipengaruhi oleh prevalensi penyakit.

Hasil dari penelitian ini didapatkan rasio kemungkinan positif adalah 5,92 sedangkan rasio kemungkinan negatif 0,17 . Hasil penelitian ini tidak berbeda jauh dengan hasil penelitian lain pada populasi dewasa oleh Maisuritadevi dkk, ${ }^{9}$ dengan menggunakan cut-offyang sama yaitu DNI 2,7\%, memiliki rasio kemungkinan positif 6,9 serta rasio kemungkinan negatif 0,11 . Pada umumnya, nilai rasio kemungkinan positif di atas 10 dan rasio kemungkinan negatif di bawah 0,1 dianggap mempunyai nilai diagnostik yang baik. ${ }^{8,10}$

Suatu studi prevalensi internasional pada tahun 2015 mendapatkan prevalensi global sepsis pada unit perawatan intensif anak $8,2 \%,{ }^{2}$ data ini dapat digunakan sebagai pre-test probability atau pravalensi. setelah mengetahui prevalensi, rasio kemungkinan uji diagnostik, dapat diketahui post-test probability (kemungkinan adanya penyakit setelah uji diagnostik). Perhitungan ini dapat dilakukan dengan bantuan normogram Fagan, tertera pada Gambar 1.

Pemeriksaan post-test probabilitas menggunakan normogram Fagan menunjukkan probabilitas positif $35 \%$, yang berarti terjadi peningkatan nilai kemungkinan $26,8 \%$ pasien menderita sepsis. Sementara itu, post-test probabilitas negatif sebesar 1,7\%.

Pemeriksaan DNI dapat memberikan gambaran fraksi granulosit kurang matang di dalam sirkulasi darah tepi. Normalnya, hampir semua neutrofil yang dilepas ke sirkulasi dari sumsum tulang dalam bentuk neutrofil segmen. Namun, dalam stres atau 
infeksi, neutrofil yang kurang matang dilepas ke sirkulasi, termasuk neutrofil batang, dan keadaan ini meningkatkan neutrofil kurang matang (immature) yang disebut pergeseran ke kiri atau left-shift, yang didefinisikan sebagai peningkatan rasio immature granulocyte / total granulosit. Pergeseran ke kiri yang lebih besar akan terbaca sebagai peningkatan nilai DNI. ${ }^{13}$ Hasil penelitian ini menunjukkan DNI memiliki rasio kemungkinan positif 5,92 dan rasio kemungkinan negatif 0,17 . Namun begitu, DNI dapat menjadi prediktor kejadian sepsis yang berguna karena dapat diukur dengan mudah juga dihitung bersamaan dengan pemeriksaan darah rutin sehingga tidak membutuhkan biaya tambahan. ${ }^{14}$ Pemeriksaan yang cepat dan murah untuk memprediksi sepsis pada pasien di unit gawat darurat ataupun ruang intensif serta diikuti pemberian terapi yang cepat akan memberikan luaran yang lebih baik.

Kelemahan penelitian ini adalah adalah jumlah sampel yang sangat terbatas, yaitu hanya 34 subjek penelitian sesuai perhitungan sampel minimal dan hanya dilaksanakan pada satu pusat penelitian. Kelemahan lain dari penelitian ini adalah rancangan penelitian yang berbentuk studi potong lintang. Rancangan studi ini tidak bisa menggambarkan perjalanan penyakit dan prognosis.

\section{Kesimpulan}

Peningkatan DNI lebih dari 2,7 meningkatkan kemungkinan terjadinya sepsis sehingga DNI dapat digunakan sebagai prediktor kejadian sepsis pada anak.

\section{Daftar pustaka}

1. Hadinegoro SR, Chairulfatah A, Latief A, Pudjiadi AH, Karyanti M, Setiabudi D, dkk. Diagnosis dan tata laksana sepsis pada diagnosis dan tata laksana sepsis pada anak.

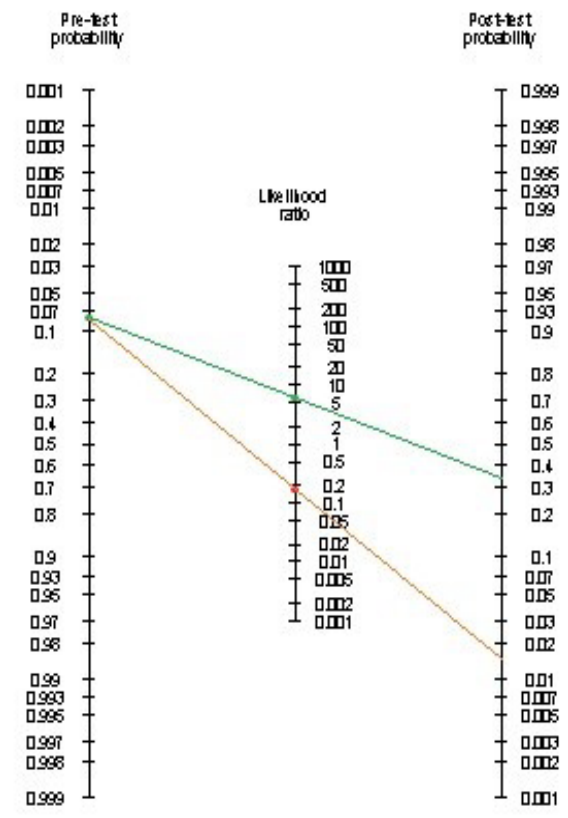

Gambar 1. Normogram Fagan. Garis hijau: RKP, garis merah: RKN ${ }^{11}$

Tabel 3. Dampak rasio kemungkinan terhadap kemungkinan terjadinya penyakit ${ }^{12}$

\begin{tabular}{lcc}
\hline Rasio kemungkinan positif & Rasio kemungkinan negatif & Kesan \\
\hline 10 & 0,1 & Sangat baik \\
6 & 0,2 & Baik \\
2 & 0,5 & Cukup \\
1 & 1 & Tidak berguna \\
\hline
\end{tabular}


Dalam: Hadinegoro SR, Chairulfatah A, Latief A, Pudjiadi A, Malisie R, Alam A, penyunting. Pedoman Nasional Pelayanan Kedokteran Ikatan Dokter Anak Indonesia. Jakarta: UKK ERIA dan Infeksi dan Penyakit Tropik IDAI; 2016.h.1-8.

2. Weiss SL, Fitzgerald JC, Maffei FA, Kane JM, RodriguezNunez A, Hsing DD, dkk. Discordant identification of pediatric severe sepsis by research and clinical definitions in the SPROUT international point prevalence study. Crit Care 2015;19:325.

3. Balamuth F, Weiss SL, Neuman MI, Scott H, Brady PW, Paul R, dkk. Pediatric Severe Sepsis in U.S. Children's Hospitals*. Pediatr Crit Care Med 2014;15:798-805.

4. Cho HY, Jung I, Kwon J-Y, Kim SJ, Park YW, Kim Y-H. The delta neutrophil index as a predictive marker of histological chorioamnionitis in patients with preterm premature rupture of membranes: A retrospective study. PLoS One 2017;12:111.

5. Seok Y, Choi JR, Kim J, Kim YK, Lee J, Song J, dkk. Delta neutrophil index: a promising diagnostic and prognostic marker for sepsis. Shock 2012;37:242-6.

6. Nahm CH, Choi JW, Lee J. Delta neutrophil index in automated immature granulocyte counts for assessing disease severity of patients with sepsis. Ann Clin Lab Sci 2008;38:2416.
7. Brakenridge SC, Efron PA, Stortz JA, Ozrazgat-Baslanti T, Ghita G, Wang Z, dkk. The impact of age on the innate immune response and outcomes after severe sepsis/septic shock in trauma and surgical intensive care unit patients. J Trauma Acute Care Surg 2018;85:247-55.

8. Sastroasmoro A, Ismael S. Telaah kritis makalah kedokteran. Dalam: S S, Ismael S, penyunting. Dasar dasar metodologi penelitian klinis. Edisi ke-2. Sagung Seto; 2002.h.341-4.

9. Maisuritadevi E. Penampilan diagnosis delta neutrophil index (DNI) dalam menegakkan diagnosis sepsis. Yogyakarta: Universitas Gadjah Mada Press; 2014.

10. Knottnerus J. Evidance based of clinical diagnosis. Evaluation of diagnostic procedures. BMJ 2002;324:477-80.

11. Akobeng A. Understanding diagnostic tests 2: Likelihood ratios, pre- and post-test probabilities and their use in clinical practice. Acta Paediatr Int J Paediatr 2007;96:487-91.

12. Salkić NN. Objective assessment of diagnostic tests validity : a short review for clinicians and other mortals. Part II. Acta Med Acad 2008;39-42.

13. Cornbleet PJ. Clinical utility of the band count. Clin Lab Med 2002;22:101-36.

14. Lee CH, Kim J, Park Y, Park YC, Kim Y, Yoon KJ, dkk. Delta neutrophil index discriminates true bacteremia from blood culture contamination. Clin Chim Acta 2013;427:11-4. 